\title{
Principal's Information Management as a Correlate to their Human Resource Management Practices in Ebonyi State
}

\author{
Paul Nwakpa \\ Department of Educational Foundations \\ Faculty of Education. Ebonyi State University \\ Abakaliki, Nigeria \\ Email: bropaulnwaoo [AT] gmail.com
}

\begin{abstract}
The study investigated the relationship between the principals' information management and their human resources management practices in Ebonyi State Public Secondary schools. The paper focused on the relationship between information management and staff orientation and relationship between information management and staff development. The study was guided by two research questions and two null hypotheses which were tested at 0.05 level of significance. The study adopted correlational research design.

The population of the study was 4,500 teachers. The sample size for the study was 450 teachers using proportionate stratified sampling technique which represents 10\% of the 4,500 teachers in Ebonyi State Public Secondary schools. Self structured type of questionnaire entitled "Human Resources and Information Management Questionnaire (HRIMQ) was used to elicit responses from the respondents. The instrument was face validated by three experts from the department of Educational Foundations, Ebonyi State University, Abakaliki. A reliability index 0.74 was obtained using cronbach co-efficient. Data collected were analyzed with Pearson product moment correlation coefficient. The study found that a significant positive relationship existed between information management and the two aspects of human resources management studied, via, staff orientation and staff development. Based on the findings of the study some recommendations were made, to include: to upgrade the information resources and facilities of schools for improve service delivery, among others.
\end{abstract}

Keywords--- Information management, Human resources management; staff orientation and Staff Development

\section{INTRODUCTION}

Secondary school education is the education given to primary schools graduates. Secondary schools form a link between the primary and tertiary levels of education (Federal Republic of Nigeria (FRN), (2014). They are an important component of human capital development Mante and Obrien (2011) and as such are valuable to the society. FRN (2014) defined Secondary education as the education children receive after primary school and before the tertiary stage. Secondary education is specifically concerned with preparing citizens for useful living within the society and for higher education. To achieve this objective, it is imperative for such schools to be effectively managed.

Effective management of schools implies a situation where the stated objectives of the school are achieved. It is a situation in which financial and capital equipment, and personnel resources are utilized effectively for the achievement of the goals of the school (Ugwoke, Ejionueme Anyanwu and Etonyeaku, 2013). Therefore, effective management of a school depends on efficient utilization of school resources, especially the school human resources.

One of the factors that contribute greatly to the success of any secondary school is the quality and strength of its staff. The principal cannot achieve success without the cooperation and support of well qualified and dedicated staff. According to Ejidike (1998) and upheld by Udalia, (2012) high quality staff is the best asset of the principal.

Therefore, the selection and development of school staff is a major task for secondary school administrators. The process of carrying out effective selection, development and retention of teachers falls within the domain of human resource management in secondary schools. Human resource management (HRM) was originally known as personnel management. Nakpodia, (2010) defined human resources management as a process of effectively using the human resources of an organization through the management of people-related activities. Personnel administration, on the other hand, is defined as the process of developing, applying and evaluating policies, procedures, methods and programmes related to individuals in the organization (Henan, 2004). Human resource management practices cuts across the entire cycle of staff management, running from selection to discharge.

The failure of principals to effectively carry out HRM practices, among which staff selection and development are key, run parallel with a pervasive under performance in general school management. Akomolafe, (2012) Ayeni (2012) and Gumede (1999) have noted severe lapses in various aspects of principals' managerial duties. Objective, reason or impetus for this study was derived from the fact that none of the studies into the causes of administrative pitfalls in human resource management in secondary schools have serious thought to how information management in secondary schools might be linked to it. This requires serious rethink. 
Already, Grieves and Hanafin (2005) had insisted that the need for information by human resource managers is most acute in these two areas. The first is in the primary task of recording when, how and with what teachers are recruited; the second is in assessing the management process in relation to how it discharged its responsibilities. There is therefore the need to turn to information management in this current effort to understand how secondary school staff may be selected and developed more appropriately for increased productivity.

Moisescu and Badescu (2012) defined information management as harnessing of organization processes and systems that acquire, create, organize, distribute and use information. Continuing, they regard the term as including all activities involved in the identification, collection, filtering, fusing, processing, focusing, dissemination and usage of information.

Principals of secondary schools are constantly faced with the need to identify, collect, filter, process, disseminate, store and use information to carry out multi furious administrative tasks. Often, this information is sought for the purpose of performing needed functions that border on the recruitment, selection, orientation, training and compensation of teachers. Information is equally relevant for such essential administrative duties like transfer, discipline and retirement of secondary school teachers.

The management of these forms of information within the school is even more important now in the light of introduction of the Nigeria Education Management Information System (NEMIS) which emphasized the need to have timely, accurate and reliable statistics for effective planning and management of education sector throughout the country (Federal Ministry of Education (FME) 2007). This does not only show the link between information and all aspects of educational management, including HRM, but also shows that effective information management at the national level depends largely on schools' ability to manage its numerous information sources.

However, it appears that schools are failing in this critical task. This is because the NEMIS document notes that: the bane of the system which is the inability to produce credible data on time has its root in the fact that schools lack everything that is basic to data generation (FME, 2007). It further added those schools' failure shows in the following, amongst others: almost lack of school record books, teachers who have not been trained to keep records and lack of monitoring to expose non-compliance.

These deficiencies found in the schools seem to indict school management in terms of inability to effectively lead their schools towards good information management. This policy statement is largely supported by several studies is this area. Adeyemi and Olaleye (2010) were particular about the low level of provision of ICT equipment to secondary schools. In Delta State of Nigeria, Regina (2011) noted poor management of school records by secondary school principals. She observed inadequately provision of record management facilities by government, including inability to organize training and retraining of school staff on record management practice.

Against this background, the need to regard information management as a major variable in HRM may not be waived off. It therefore becomes imperative to find out if Ebonyi State public secondary school principals' management of information about teachers and their human resources management practices are correlates.

\section{STATEMENT OF THE PROBLEM}

A good number of studies conducted however show that despite considerable emphasis on selection, orientation, staff training and development of school staff, most of the principals seem not to have been able to develop a high quality staff that would drive school progress. This points to the fact that there could be much more to what influence effective HRM than what was previously, known.

The present study identified information management as the likely variable that stands between the desire for improved HRM practices and its effective realization. In order to discover if information management is really a major variable that determines the success or failure of HRM, there is need to scientifically find out the nature of the relationship between both variables. This is then, the problem this study was set to solve.

\section{PURPOSE OF THE STUDY}

The main purpose of this study was to determine the relationship between principals' information management and their staff orientation and staff development practices and their effects on output.

\section{RESEARCH QUESTIONS}

Two research questions guided the study.

1. What is the relationship between principals' information management performance and their staff orientation practices?

2. What is the relationship between principals' information management performance and their staff development practices?

\section{HYPOTHESES}

The following two null hypotheses guided the study.

1. There is no significant relationship between principals' information management performance and their staff orientation practices. 
2. There is no significant relationship between principals' information management performance and their staff development practices.

\section{METHODOLOGY}

A correlational design was adopted in the study covering the entire public secondary schools in Ebonyi State. The state has 13 Local government areas with 3 education zones, namely, Abakaliki, Afikpo and Onueke. The population was 4,500 teachers. A sample of the population was 450 teachers drawn using stratified proportionate random sampling. Thus, the State was stratified into three zones, proportionately ten schools were randomly selected from each zone and 15 teachers were randomly selected from each of the selected schools.

Data collection in this study was done with a set of questionnaire developed by the researcher, titled, "Human Resources and Information Management Questionnaire (HRTMQ). The instrument was face validated by three experts in the department of Educational foundations, Ebonyi State University, Abakaliki. The cronbach alpha was used in obtaining the reliability of the instrument which yielded 0.76 .

The instrument was administered on the respondents with the help of 6 research assistants. There after, the researcher used Pearson's product moment correlation to answer the research questions as well as the null hypotheses at 0.05 level of significance.

\section{RESULTS}

Analysis of the data collected was done according to research questions and hypotheses in tables.

Research Question 1: What is the relationship between principals' information management performance and their staff orientation practices?

Table 1: Pearson's Collection between principals' information management practice of staff orientation and their staff level of productivity.

\begin{tabular}{llllll}
\hline No of Respondents & $\begin{array}{l}\sum x \text { scores on orientation } \\
\text { product. }\end{array}$ & $\begin{array}{l}\sum y \text { score staff level of } \\
\text { productive }\end{array}$ & $\sum x y$ & $\sum x^{2}$ & $\sum y^{2}$ \\
\hline 450 & 98.5 & 78.3 & 273.96 & 376.5 & 213.2
\end{tabular}

In table 1 , the " $r$ " value is 0.92 this value is high positive because, it is close to +1 than -1 . The conclusion therefore, is that there is a high positive relationship between utilization of information management on staff orientation and staff productivity.

Research Question Two: There is no significant relationship between principals' information management performance and their staff development practices.

Table 2: Pearson's Correlation between principals' information management practice of staff development and their staff level of productivity.

\begin{tabular}{llllll}
\hline No of Respondents & $\begin{array}{l}\sum \mathrm{X} \text { scores on staff deve. } \\
\text { practices }\end{array}$ & $\begin{array}{l}\sum \text { y score on staff level of } \\
\text { productive }\end{array}$ & $\sum \mathrm{xy}$ & $\sum \mathrm{x}^{2}$ & $\sum \mathrm{y}^{2}$ \\
\hline 450 & 96.8 & 91.5 & 378.6 & 215.7 & 213.4
\end{tabular}

Table 2, the " $r$ " value is 0.96 . This value is high positive because it is close to +1 than -1 . The conclusion is therefore that there is a high positive relationship between utilization of information management on staff development and staff productivity.

HO1: There is no significant relationship between principals' information management performance and their staff orientation practices.

Table 3: Test of significance of Pearson's correlation between principals' utilization of information management of staff orientation and their level of productivity.

\begin{tabular}{lllllll}
\hline $\mathrm{N}$ & $\mathrm{r}$ & $\mathrm{df}$ & $\mathrm{t}-\mathrm{cal}$ & $\mathrm{t}$-crit & Level of significance & Decision \\
\hline 450 & 0.92 & 448 & 19.94 & 1.96 & 0.05 & $\mathrm{HO}_{1}$ Reject.
\end{tabular}

As shown in table 3, the t-cal calculated value of 19.94 is greater item that t-critical value of 1.96 , given degrees of freedom 448 and 0.05 significant level. This leads to the rejection of the null hypothesis which stated that there is no significant relationship between principals' utilization of information management of their staff orientation and their level of productivity. Therefore, there is significant relationship between principals' utilization of information management of their staff orientation and their level of productivity.

H02: There is no significant relationship between principals' information management performance and their staff development practices.

Table 4: Test of significance of Pearson's correlation between principals' utilization of information management of staff development and their staff level of productivity.

\begin{tabular}{lllllll}
\hline $\mathrm{N}$ & $\mathrm{r}$ & $\mathrm{df}$ & $\mathrm{t}-\mathrm{cal}$ & $\mathrm{t}$-crit & Level of significance & Decision \\
\hline 450 & 0.96 & 448 & 21.35 & 1.96 & 0.05 & $\mathrm{HO}_{2}$ Reject $^{2}$
\end{tabular}


As shown in table 4, the t-calculated value of 21.35 is greater than the t-critical value of 1.96 given degrees of 448 and 0.05 significant level. This leads to the rejection of hypothesis two that is stated that there is no significant relationship between principals' utilization of information management of their staff development and their level of productivity. Thus, there is significant relationship between principals' utilization of information management of their staff development and their staff level of productivity.

\section{SUMMARY OF MAJOR FINDINGS}

The study was set to examine if principals' human resources management and their information management practices in Ebonyi State Public secondary schools are correlate.

It is revealed that the principals' information management of staff orientation and their staff level of productivity have positive relationship. Thus, staff level of output depends largely on principals' information management of staff orientation.

It further revealed that the principals' information management of staff development and their staff level of productivity have high positive relationship. Thus, staff level of performance is dependent on principals' information management of staff development programmes.

\section{DISCUSSION OF FINDINGS}

The study first and foremost revealed strong positive relationship between principals' information management of staff orientation practices and staff level of productivity. With respect to the research question, this indicates that an increase in principals' information management performance with regard to staff orientation will lead to a corresponding increase in teachers' output.

This finding is in line with the view of Lunenberg (2011) who held that the effectiveness of principals' orientation programmes is hinged, among other things, on a proper management of information concerning the needs and interests of the beginning teacher.

This is further supported by Coombs (2001) whose study on the effect of information management technology on human resources management explored by the US civil service.

Therefore, the hypothesis that there is no significant relationship between principals' information management of staff orientation and their staff level of productivity in Ebonyi State Public Secondary schools was not supported by available data in this study. This shows that poor management of information regarding newly recruited staff could mar the conduct of effective orientation programme, for beginning teachers, and could be responsible for the inability of staff orientation programmes to engender improved staff productivity as witnessed in Ebonyi State Public Secondary schools.

In the case of information management and staff development, a strong positive relationship between principals' information management and staff development was recorded. This is an indication that principals who manage information about their staff very well will tend to develop their staff to a considerable high extent. On the other hand, principals who cannot effectively manage staff information will tend to score low in staff development. This finding agrees with Hayajneh, al-omari, al-mobaideen and Ahawiah (2013) who found that human resources information system (HRIS) impact very high on the identification of training programmes, evaluation of training and follow-up in order to discover the effectiveness of training in organizations.

Mayfield, Mayfield and Lunce (2003) and Sehuler (2001) also claimed that the contemporary use of Information Systems (IS) in the Human Resources Management (HRM) process has improved the decision making ability of organization management. Therefore, the hypothesis that there is no significant relationship between principals' information management and their staff development practices in Ebonyi State Public Secondary Schools was not validated by an available data. Poor management of the use of staff development programmes to engender improved staff productivity explaining why many staff development programmes in Ebonyi State Public Secondary Schools have not been effective and successful.

\section{CONCLUSION}

Emphatically, it could be conducted that effective information management practices consisting of the ability to accurately identify, collect, analyze, store, retrieve and disseminate information about other staff is linked with the ability of principals to properly carry out human resources management practices, namely, orientation and development of school staff. It can also be said that poor information management is linked with poor performance in human resources management. In other words, where principals are not able to adequately identify, collect, analyze, store, retrieve and disseminate information about their staff, their performance of human resources management functions like orientation, development, motivation and discipline of staff will be very low and poor.

\section{RECOMMENDATIONS}

Based on the results of the study, the following recommendations were made:

1. Principals should regard the management of information about their staff as being very important, not only for purposes of general school administration but as making a heavy input into human resource management.

2. Principals should seek to know more about their teachers and to understand that any knowledge gained by so doing, through written, oral, formal and informal media will undoubtedly result to improved human resource management. 
3. In human resource information system, professionals should include those issues that are core to the management of teachers such as orientation development or training, motivation, discipline, supervision into their work.

\section{REFERENCES}

- Adeyemi, T. O. \& Olayele, F.O. (2010). Information Communication Technology (ICT) for effective management of secondary schools for sustainable development in Ekiti State. American Journal of Scientific Research, (2), 106-113.

- Akomolafe, C. (2012). A comparative study of principals' administrative performance in public and private schools in Ekiti State, Journal Educational Theory and Practice, 3 (13).

- Anenberg, F.C. (2011) Orientation and induction of the beginning teacher. National Administration and Supervision Journal, 28(4)12-15.

- Ayeni, A.J. (2012). Assessment of principals' supervisory roles for quality assurance in secondary schools in Ondo State, Nigeria. World Journal Education, 2 (1).

- Ejidike, A.N. (1998). Evaluation of human resource management in secondary schools by male and female principals in Onitsha Educational Zone Anambra State. Unpublished Masters' thesis. University of Nigeria, Nsukka.

- Federal Republic of Nigeria, (2014). National policy on education and 4-year strategic plan for the development of the education sector. 2011-2015. Lagos: NERDC Press.

- Grieves, J. \&Hanafin, P. (2005). Human resources management: The Achilles heel of school governance. Employee Relations, 27, 1/2 Pro Quest, 20.

- Gumede, M.G. (1999). An evaluative study of the administrative process by secondary school principals in the Durban South Region. Unpublished. Master's thesis. University of Zululand.

- Hayajneh, M., Al-Omari, B.M., Al-Mobaiseen, H.O. \&Ahawiah, S. (2013). The Impact of Human Resource Information Systems in improving the training Processing industrial firms: Aqaba City case study. European Scientific Journal, 8 (25), 1-19.

- Henan, Y. (2004). From personnel administration to human resources management: A case study of state owned enterprises in China. Unpublished Master's thesis. City University of Hong Kong.

- Hilloss, M (2004). Personnel management and crises situations. The Sweedish School of Economic and Business Administration, 3(136).

- Mante B. \& O’Brian, G. (2001). Efficiency measurement of Australian public sector organizations. Journal of Educational Administration, 40(3), 274-89

- Mayfield M., Mayfield, J. \& Lunce, S. (2003). Human resources information systems. A review and model development. Advances in competitiveness research, 11(39)

- Moisescu, N. \& Badescu (2012). Information management support for strategic management. Regional Department of Defence Resources Management Studies, 4 (9), 44-49.

- Nakpodia E.D. (2010).Human resources management in school administration in Delta State. Journal of Social Sciences, 23 (3), 179-187.

- Nwosu A.A. (2003). Integrating ICT into SMT classrooms: status and implications. Proceedings of the $44^{\text {th }}$ Stan Conference, 58-60.

- Olugbeye A. (2004). Introduction to educational management in Nigeria. Ibadan: Daily Graphics LTD. 
- Regina, S.N. (2011). Management of school records by secondary school principals in Delta State, Nigeria. Medwell Journal, 6(1), 40-44.

- Schuller, R.S., Dolan, S. \& Jackson, S.E. (2001). Introduction. International Journal of Manpower, 22 (5), 195 -7.

- Squier, M.M. (2003). The principles and practice of knowledge management. Unpublished Master's thesis. University of Pretoria.

- Thompson J. \& Kleiner, B.I. (2005). Effective human resources management of school districts. Management Research News, 28 (3), ProQuest p.42.

- Ugwuoke, S.C., Ejionueme, L.K., Anyanwu, J.I. \& Etonyeaku, E.A.C. (2013). Analysis of principals' human resource management practices in secondary schools in Nsukka Educational Zone, Enugu State. Psychology Research, 3(1), 12-21. 